\title{
KINETICS OF THE PRECIPITATION IN AUSTENITE HSLA STEELS
}

\author{
KINETIKA IZLOČANJA V AVSTENITNIH HSLA-JEKLIH
}

\author{
Elżbieta Kalinowska-Ozgowicz ${ }^{1}$, Roman Kuziak², Wojciech Ozgowicz ${ }^{3}$, \\ Klaudiusz Lenik ${ }^{1}$ \\ ${ }^{1}$ Lublin University of Technology, Fundamentals of Technology, Nadbystrzycka Str 38, 20-618 Lublin, Poland \\ 2Institute for Ferrous Metallurgy, K. Miarki Str 12-14, 44-100 Gliwice, Poland \\ ${ }^{3}$ Silesian University of Technology, Mechanical Engineering Faculty, Konarskiego Str 18a, 44-100 Gliwice, Poland \\ kalinowska-ozgowicz@tlen.pl
}

Prejem rokopisa - received: 2014-07-30; sprejem za objavo - accepted for publication: 2014-11-06

doi:10.17222/mit.2014.139

\begin{abstract}
Presented are the results of an investigation of the kinetics of the static precipitation in HSLA steels with microalloying additions of $\mathrm{Nb}, \mathrm{V}, \mathrm{Ti}$ and high $\mathrm{N}$ between the consecutive hot plastic-deformation cycles. The hot plastic deformation was carried out using a torsional plastometer and a Gleeble thermomechanical simulator. The kinetics curves of the precipitation process in the examined steels were determined based on the changes in the values of strain $\varepsilon_{\mathrm{m}}$ in the flow curves during continuous and interrupted deformations. The precipitation process in the austenite of the examined steels was investigated using transmission electron microscopy of the test specimens quenched immediately after hot deformation and held isothermally for various times. The precipitation effects inherited in the martensite were analysed with electron diffraction and X-ray
\end{abstract} microanalysis.

Keywords: hot plastic deformation, kinetics of precipitation, HSLA steels, structure, Gleeble simulator

Predstavljeni so rezultati preiskave kinetike statičnega izločanja v HSLA-jeklih, mikrolegiranih z Nb, V, Ti in visokim N med zaporednimi cikli vroče plastične deformacije. Vroča plastična deformacija je bila izvršena s torzijskim plastometrom in $\mathrm{z}$ Gleeble-jevim termomehanskim simulatorjem. Krivulje kinetike procesa izločanja v preiskovanih jeklih so bile ugotovljene na podlagi sprememb vrednosti napetosti $\varepsilon_{\mathrm{m}}$ in krivulj tečenja med kontinuirnimi in prekinjenimi deformacijami. Proces izločanja $\mathrm{v}$ avstenitu preiskovanih jekel je bil preiskovan s presevno elektronsko mikroskopijo preizkusnih vzorcev, kaljenih takoj po vroči deformaciji in različno dolgem izotermnem zadrževanju. Podedovani učinki izločanja v martenzitu so bili analizirani z difrakcijo elektronov in rentgensko mikroanalizo.

Ključne besede: vroča plastična deformacija, kinetika izločanja, HSLA-jekla, struktura, Gleeble-jev simulator

\section{INTRODUCTION}

Chemical compositions and structural changes of HSLA steels during a hot plastic deformation are the basic sources of the diversity of the mechanical properties of finished products. Shaping the mechanical properties of this group of steels takes place by inducing the relevant strengthening mechanisms and by developing proper phase compositions of steels. ${ }^{1-3} \mathrm{~A}$ decisive role in shaping the mechanical properties of microalloyed steels is played by the precipitates of secondary interstitial phases (MX-type carbo-nitrides formed as a result of alloying the microalloying elements of $\mathrm{Nb}, \mathrm{Ti}$, $\mathrm{V}$ and $\mathrm{N}$ into steel, i.e., carbides and nitrides as well as the products of their intersolubility - carbonitrides. The stability of these phases depends mainly on their chemical compositions and solution temperatures..$^{4-8}$ The knowledge of the basic thermodynamic data of the analysed compounds makes it possible to use them in hot-working processes such as: controlled rolling, rolling with controlled recrystallisation, finish rolling and thermomechanical treatments. ${ }^{9-11}$ HSLA microalloyed steels with ferritic-pearlitic structures obtain relatively high mechanical properties due to the grain refinement and precipitation hardening.

\section{EXPERIMENTAL PROCEDURE}

The studies of the kinetics of the precipitation were carried out on HSLA microalloyed constructional steels with ferritic-pearlitic structures obtained from industrial

Table 1: Chemical compositions of investigated steels in mass fractions, $w / \%$

Tabela 1: Kemijska sestava preiskovanih jekel v masnih deležih, w/\%

\begin{tabular}{|c|c|c|c|c|c|c|c|c|c|c|c|}
\hline \multirow{2}{*}{ Steel type } & \multicolumn{11}{|c|}{ Concentration of the elements in $w / \%$} \\
\hline & $\mathrm{C}$ & $\mathrm{Mn}$ & $\mathrm{Si}$ & $\mathrm{P}$ & $\mathrm{S}$ & $\mathrm{Nb}$ & $\mathrm{V}$ & $\mathrm{Ti}$ & $\mathrm{N}$ & $\mathrm{Al}$ & $\mathrm{Cu}$ \\
\hline B2 & 0.15 & 1.03 & 0.25 & 0.018 & 0.009 & 0.017 & 0.050 & - & 0.0070 & 0.004 & - \\
\hline G1 & 0.16 & 1.48 & 0.29 & 0.030 & 0.017 & 0.037 & 0.002 & 0.004 & 0.0098 & 0.010 & 0.049 \\
\hline
\end{tabular}


heats. The chemical compositions of the examined steels are given in Table $\mathbf{1}$.

For steels B2 and G1 the studies of the kinetics of the precipitation of carbides and carbonitrides were carried out and PTT (precipitation-temperature-time) diagrams were developed for various austenite deformation conditions and isothermal holding times of the following deformation sequences.

A static precipitation in the non-deformed austenite of the B2 steel was performed in a torsional plastometer and test specimens of $6 \mathrm{~mm}$ in diameter and $10 \mathrm{~mm}$ in gauge length were used. The specimens were heated at 3 ${ }^{\circ} \mathrm{C} / \mathrm{s}$ to the austenitizing temperature of $1150{ }^{\circ} \mathrm{C}$, held for $360 \mathrm{~s}$, cooled to a deformation temperature of $900{ }^{\circ} \mathrm{C}$ at approximately $10{ }^{\circ} \mathrm{C} / \mathrm{s}$ and held isothermally for $6 \mathrm{~s}$ to $10800 \mathrm{~s}$, then deformed at a rate of $4.4 \mathrm{~s}^{-1}$ until a failure (torsion) took place. The heating was performed in the plastometer's resistance-heat furnace, in an argon atmosphere. The austenitizing and deformation temperatures were measured with a radiation pyrometer with an accuracy of $\pm 1^{\circ}$. The cooling of the test specimens to room temperature, immediately after the hot deformation, was performed with a water jet from the plastometer's hydraulic system. An analysis of the value of deformation corresponding to the maximum stress on the $\sigma-\varepsilon$ curves as a function of the isothermal holding time, enabled us to determine ${ }^{3}$ the characteristic times of the beginning $\left(P_{\mathrm{s}}\right)$ and the end $\left(P_{\mathrm{f}}\right)$ of the precipitation process in the non-deformed austenite of the B2 steel.

For the G1 steel, the precipitation process was investigated in the non-deformed state and after a hightemperature deformation of the austenite using the cyclic axisymmetric-upsetting and stress-relaxation methods. The investigations were performed on a Gleeble 3800 simulator using cylindrical test specimens of $7 \mathrm{~mm}$ in diameter and $8.4 \mathrm{~mm}$ in length. The specimens were heated at $3{ }^{\circ} \mathrm{C} / \mathrm{s}$ to an austenitizing temperature of 1200 ${ }^{\circ} \mathrm{C}$, held for $3 \mathrm{~s}$, cooled to a deformation temperature of $1100{ }^{\circ} \mathrm{C}$ at approximately $1.0{ }^{\circ} \mathrm{C} / \mathrm{s}$ and held isothermally for $2 \mathrm{~s}$ to $1800 \mathrm{~s}$, then deformed at $1.0 \mathrm{~s}^{-1}$ to $\varepsilon=1$. In the stress-relaxation method, the precipitation process was investigated in the austenite deformed to $\varepsilon=0.2$ at 800 ${ }^{\circ} \mathrm{C}$ to $1100{ }^{\circ} \mathrm{C}$ after an austenitization at $1200{ }^{\circ} \mathrm{C}$, keeping the same strain parameters as for the cyclic compression test. The heating of the test specimens in the simulator was performed with the resistance method and in an argon atmosphere. To reduce the coefficient of friction, the faces of the test specimens were coated with a graphite-and-tantalum foil.

The microstructures of the G1 steel after the selected hot deformation and precipitation stages were determined with transmission electron microscopy (TEM) using the selective electron diffraction and energy-dispersive X-ray spectroscopy (EDX) methods. In the investigations, an S/TEM Titan 80-300 scanning electron microscope by FEI, fitted with a field electron gun (XFEG), an energy-dispersion spectrometer (EDS), an external energy filter for imaging (EFTEM) and for spectroscopy (EELS) as well as a system of BF/ADF/ HAADF detectors for the operations of the scanning system were used. Observations were performed within the scope of $245-300 \mathrm{kV}$, in a classic TEM system with a spatial resolution of the network image below $0.10 \mu \mathrm{m}$ and using the microscope's field emission gun to allow the electron beam to be focused up to $0.3 \mathrm{~nm}$ during the observation of high-resolution images (HRTEM). Microstructures were observed on the foils and small lamellas. The foils were obtained by mechanical thinning and ion polishing using a Gatan PIPS polishing machine, while the lamella-formed preparations of $20 \mu \mathrm{m} \times 8 \mu \mathrm{m}$ were cut out with a gallium-focused ion beam from a specific cross-sectional area of the test specimen and then thinned with this ion beam to a thickness of approximately 50-70 nm using a FEI FIB Quanta 3D200 machine. The lamella-preparation process was observed in situ using the scanning electron microscope.

The procedure of a phase identification based on electron diffraction was supported with the ELDYF software for indexing and simulating electron diffraction patterns.

\section{RESULTS AND DISCUSSION}

The results of the kinetics of the static precipitation in the microalloyed constructional steels (B2 and G1) are shown in Figures $\mathbf{1}$ to 6. In particular, for the B2 steel, the kinetics of the static precipitation in the austenite not deformed by the hot torsion was determined (Figure 1), while, for the G1 steel, the precipitation process was determined for the austenite in the non-deformed state and after a high-temperature deformation (Figures 2 to 5). It was found that an increase in the holding time before the deformation resulted in a distinct reduction in the values of $\varepsilon_{\mathrm{m}}$ and the corresponding maximum stresses. This effect is equivalent to the reduction in the degree of strain hardening of the austenite and results from the growing share of the static precipitation during

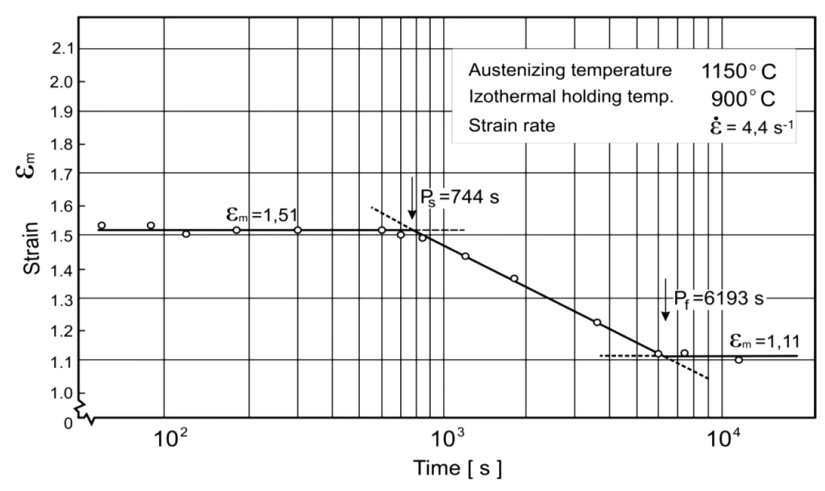

Figure 1: Kinetics of the static precipitation in non-deformed austenite of microalloyed steel B2, determined with a hot-deformation test

Slika 1: Kinetika statičnega izločanja v nedeformiranem avstenitu mikrolegiranega jekla B2, določena s preizkusom vroče deformacije 
the isothermal holding. Thereby, the potential for dynamic precipitation at the stage of hardening is decreasing, which, in turn, results in a reduced degree of inhibition of dynamic recrystallization and the observed changes in $\varepsilon_{\mathrm{m}}$ for the values of $\sigma_{\max }$. Therefore, in the absence of precipitation before the deformation, the constant and maximum value of $\varepsilon_{\mathrm{m}}$ is obtained (Figures $\mathbf{1}$ and 2). It is connected with the maximum solubility of $\mathrm{Nb}$ in the austenite, potentially inhibiting the nucleation process of dynamic recrystallisation so that the precipitation process leads to a stabilisation of the $\varepsilon_{\mathrm{m}}$ values at the minimum level, observed at the stage of the stress increase in the flow curves. The end of the first plateau and the beginning of the next one on the kinetic curves were adopted as the times of the beginning $\left(P_{\mathrm{s}}\right)$ and the end $\left(P_{\mathrm{f}}\right)$ of the static precipitation in the examined microalloyed steels.

The static precipitation process in the B2 steel after the austenitization at $1150{ }^{\circ} \mathrm{C}$ and isothermal holding at $900{ }^{\circ} \mathrm{C}$ starts after approximately $740 \mathrm{~s}$ and ends after approximately $6200 \mathrm{~s}$ (Figure 1). Before the start of the precipitation in the $\mathrm{B} 2$ steel, the value of $\varepsilon_{\mathrm{m}}$ is 1.51 and after its completion it is $\varepsilon_{\mathrm{m}}=1.11$. During the precipitation the relationship between strain $\varepsilon_{\mathrm{m}}$ and the isothermal holding time can be described with a linear function $\left(\varepsilon_{\mathrm{m}}=-0.43 \cdot \lg \tau+2.67\right)$ whose intersection points determine the times of the beginning and the end of the precipitation process.

In the case of the isothermal holding of microalloyed steel $\mathrm{G} 1$ at $1100{ }^{\circ} \mathrm{C}$ after the austenitization at $1200{ }^{\circ} \mathrm{C}$, the relationship between $\varepsilon_{\mathrm{m}}$ and the time is described in a similar way. The first stage, the period of up to $47 \mathrm{~s}$, is described as $\varepsilon_{\mathrm{m}}=0.53$, while the second stage (to approximately $1380 \mathrm{~s}$ ) is described with the linear function $\varepsilon_{\mathrm{m}}=-0.1 \lg \tau+0.7$. When the isothermal holding $\tau>$ $1380 \mathrm{~s}$, the third section with a stabilised value is described with the formula $\varepsilon_{\mathrm{m}}=0.37$. The inflexion points of the function determine the times of the beginning $\left(P_{\mathrm{s}}=47 \mathrm{~s}\right)$ and the end $\left(P_{\mathrm{f}}=1380 \mathrm{~s}\right)$ of the static precipitation in the non-deformed austenite of the examined

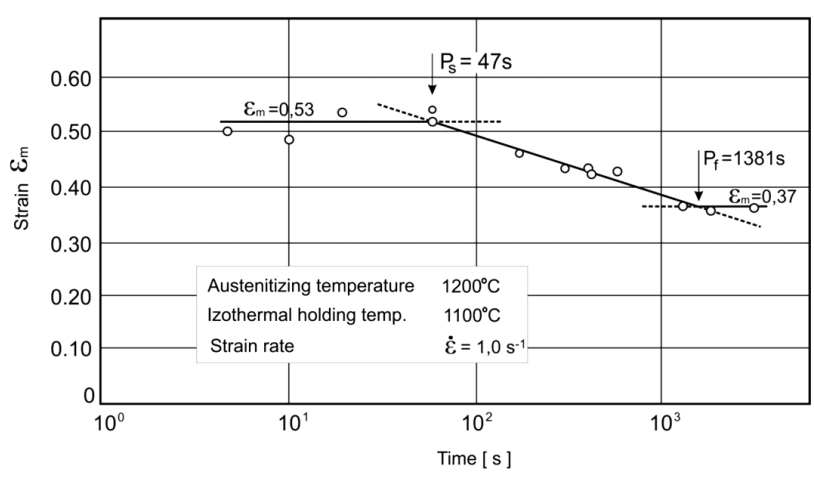

Figure 2: Kinetics of the static precipitation in non-deformed austenite of microalloyed steel G1, determined with a hot-compression test Slika 2: Kinetika statičnega izločanja $v$ nedeformiranem avstenitu mikrolegiranega jekla G1, določena z vročim tlačnim preizkusom microalloyed steel at the holding temperature of $1100{ }^{\circ} \mathrm{C}$ (Figure 2).

The static precipitation process was also analysed in the microalloyed steel G1 using the two-stage compression method after the austenitization at $1200{ }^{\circ} \mathrm{C}$ and the pre-strain of the test specimens $(\varepsilon=0.2)$ before the isothermal holding at $1100{ }^{\circ} \mathrm{C}$. The diagram of the changes in $\varepsilon_{\mathrm{m}}$ during the isothermal holding is also characterised by three stages (Figure 3 ). In the initial stage, there is a constant value, $\varepsilon_{\mathrm{m}}=0.42$, then this value changes linearly to settle again at a strain level of $\varepsilon_{\mathrm{m}}=$ 0.62 for a longer holding time. The characteristic inflexion points of the diagram determine similarly the time of the beginning and the end of the static precipitation in the non-deformed austenite. The process takes place during the isothermal holding after the plastic deformation from approximately $13 \mathrm{~s}$ to approximately $28 \mathrm{~min}$.

For comparison, the static precipitation in the microalloyed steel G1 was also investigated, with the stressrelaxation method, after the austenitization at $1200{ }^{\circ} \mathrm{C}$ and the preliminary compression of the test specimens within a temperature range of $800-1100{ }^{\circ} \mathrm{C}$, using the Gleeble thermodynamic simulator. The times of the beginning and the end of the static-precipitation process were determined analytically and shown graphically in diagrams (Figures 4 to 6). The values of the pre-strain $(\varepsilon=0.2$ and 0.4 ) were found to have a slight impact on the time to the initiation of the precipitation $\left(P_{\mathrm{s}}\right.$ was approximately $17 \mathrm{~s}$ ) at $900{ }^{\circ} \mathrm{C}$, while for the maximum value of the strain $(\varepsilon=0.6)$ the corresponding time was twice as high. The static precipitation at this temperature ends, regardless of the size of the pre-strain, after approximately $3 \mathrm{~min}$ (Figure 5). The precipitation at a lower deformation temperature $\left(800{ }^{\circ} \mathrm{C}\right)$ is evident in the distinct plateau on the stress-relaxation curve and it takes place within the period from $P_{\mathrm{s}}$ of approximately $30 \mathrm{~s}$ to $P_{\mathrm{f}}$ of approximately $600 \mathrm{~s}$ (Figure 5). The studies imply that for the austenite deformed before the isothermal

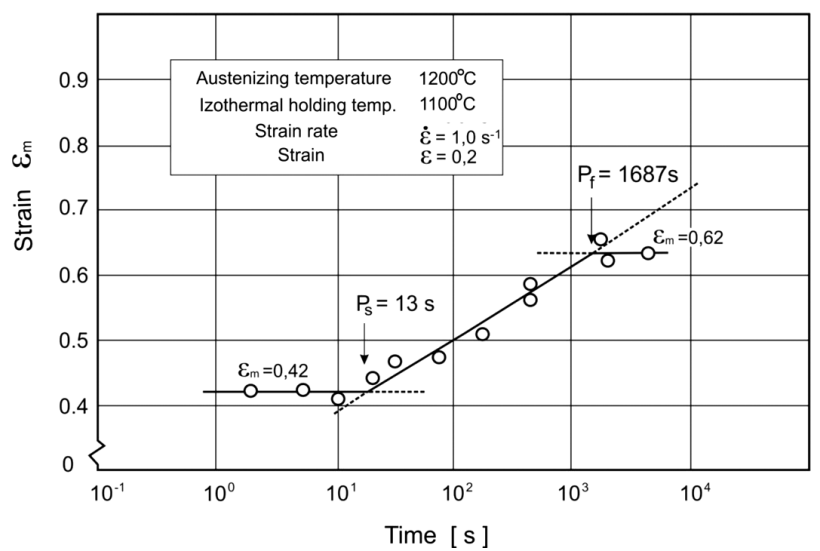

Figure 3: Kinetics of the static precipitation in deformed austenite of microalloyed steel G1, determined with a hot-compression test

Slika 3: Kinetika statičnega izločanja $\mathrm{v}$ deformiranem avstenitu mikrolegiranega jekla $\mathrm{G} 1$, določena z vročim tlačnim preizkusom 


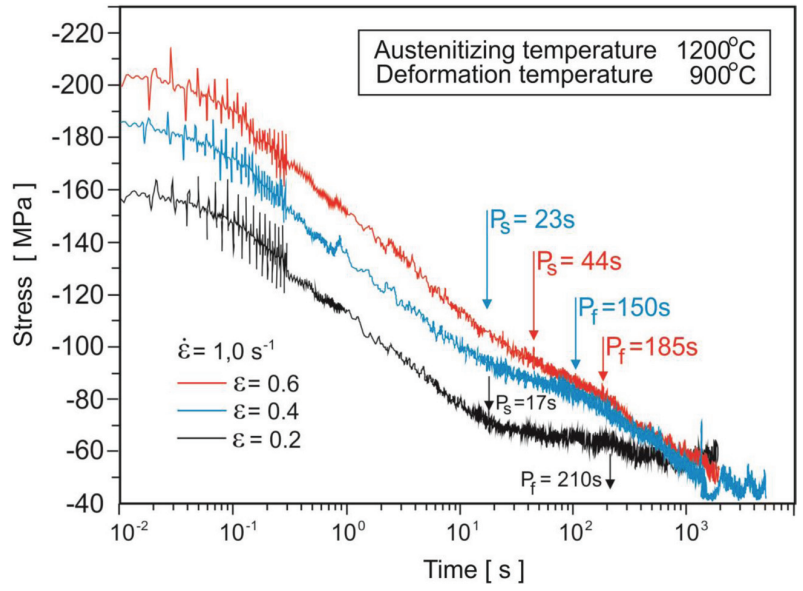

Figure 4: Stress-relaxation curves for microalloyed steel G1 subject to a hot-compression test at $900{ }^{\circ} \mathrm{C} ; P_{\mathrm{s}, \mathrm{f}}$ - times of the beginning and end of the static precipitation process

Slika 4: Krivulje zmanjševanja napetosti pri mikrolegiranem jeklu G1 pri vročem tlačnem preizkusu na $900{ }^{\circ} \mathrm{C} ; P_{\mathrm{s}, \mathrm{f}}-$ časi do začetka in konca statičnega procesa izločanja

holding of the G1 steel, the time to the beginning of the static precipitation is clearly shorter than the corresponding time for the non-deformed austenite. The kinetic analysis also revealed that the times of the end of the static-precipitation process in both cases (non-deformed austenite and the austenite deformed before the isothermal holding) are comparable.

The analysis of the results of the kinetics obtained for the examined microalloyed steel G1, considering the austenite before the isothermal holding as well as the conditions of the high-temperature deformation, allowed PTT curves to be determined (Figure 6). The static-precipitation curves obtained for the austenite of the G1 steel in the investigated conditions of hot deformation indicate that the precipitation process is the fastest at the isothermal-holding temperature of $900{ }^{\circ} \mathrm{C}$. The times of

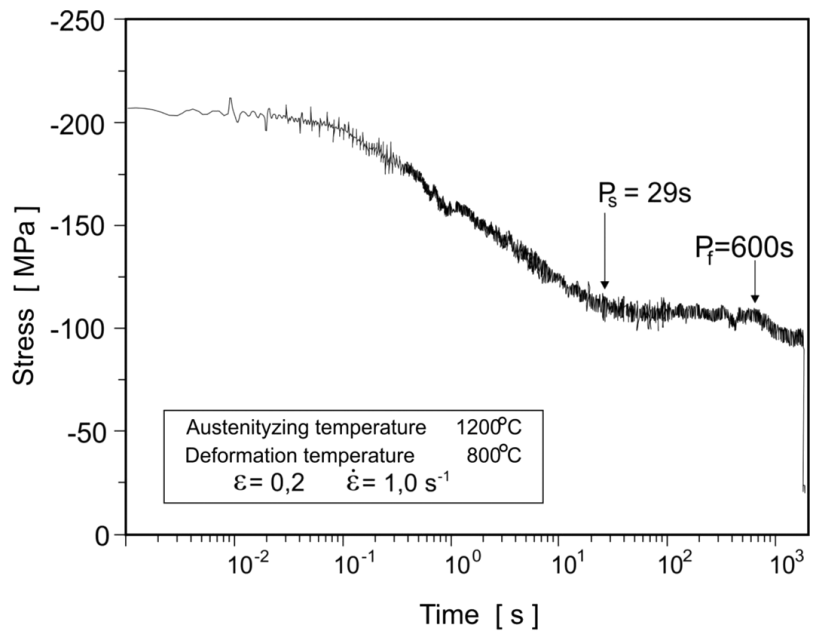

Figure 5: Stress-relaxation curve for microalloyed steel G1 subject to a hot-compression test at $800{ }^{\circ} \mathrm{C}$

Slika 5: Krivulja zmanjševanja napetosti pri mikrolegiranem jeklu G1 po vročem tlačnem preizkusu pri $800{ }^{\circ} \mathrm{C}$

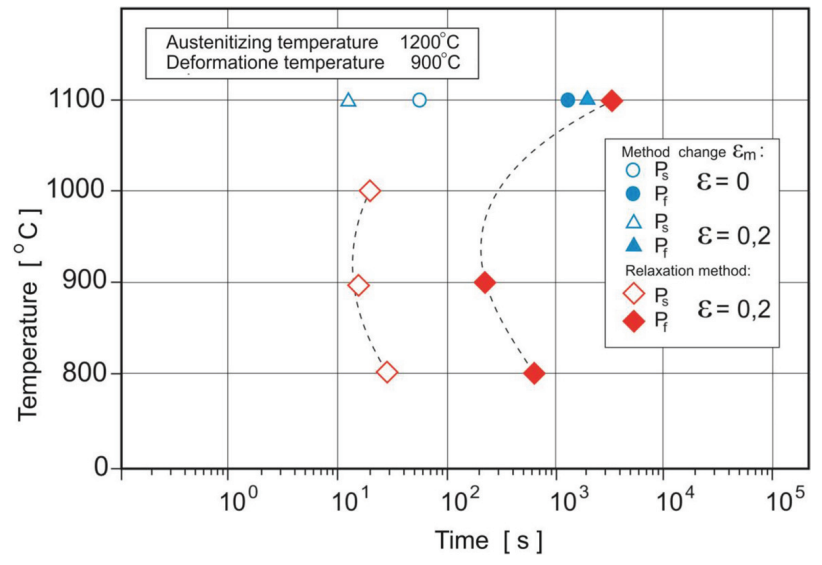

Figure 6: Results of the studies of the kinetics of the static precipitation (PTT) for microalloyed steel G1 subject to plastic deformation with the hot-compression method

Slika 6: Rezultati študija kinetike statičnega izločanja (PTT) za mikrolegirano jeklo G1 po plastični deformaciji z metodo vročega stiskanja

the initiation and the end of the precipitation are $17 \mathrm{~s}$ and $210 \mathrm{~s}$, respectively. The times of the initiation of the precipitation at both higher $\left(1000{ }^{\circ} \mathrm{C}\right)$ and lower $\left(800{ }^{\circ} \mathrm{C}\right)$ temperatures are longer, $22 \mathrm{~s}$ and $30 \mathrm{~s}$, respectively. The end of the precipitation process at $800{ }^{\circ} \mathrm{C}$ takes place after approximately $10 \mathrm{~min}$.

The precipitation process in the G1 steel was investigated on the test specimens quenched in water immediately after the hot deformation and isothermal holding for various periods. The phase-precipitation effects
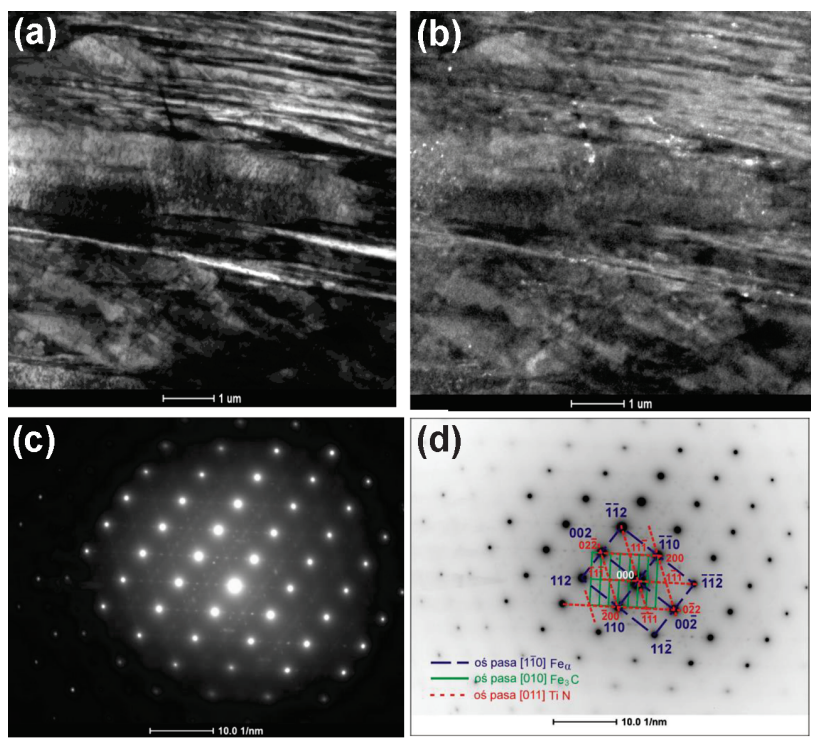

Figure 7: a) Microstructure of martensite lath with $\mathrm{Fe}_{3} \mathrm{C}$ and $\mathrm{TiN}$ precipitates, b) image in the dark field, c) diffraction, d) diffraction solution; G1 steel, $T_{\mathrm{A}}=1200{ }^{\circ} \mathrm{C}, T_{\mathrm{def}}=1100{ }^{\circ} \mathrm{C}, \dot{\varepsilon}=1.0 \mathrm{~s}^{-1}, \varepsilon=0.2$, $\tau_{\mathrm{w}}($ water $)=30 \mathrm{~s}$

Slika 7: a) Mikrostruktura latastega martenzita $\mathrm{z} \mathrm{Fe}_{3} \mathrm{C}$ in izločki TiN, b) posnetek $\mathrm{v}$ temnem polju, c) difrakcija, d) difrakcija indeksirana; jeklo $\mathrm{G} 1, T_{\mathrm{A}}=1200{ }^{\circ} \mathrm{C}, T_{\mathrm{def}}=1100{ }^{\circ} \mathrm{C}, \dot{\varepsilon}=1,0 \mathrm{~s}^{-1}, \varepsilon=0,2, \tau_{\mathrm{w}}$ (voda) $=30 \mathrm{~s}$ 

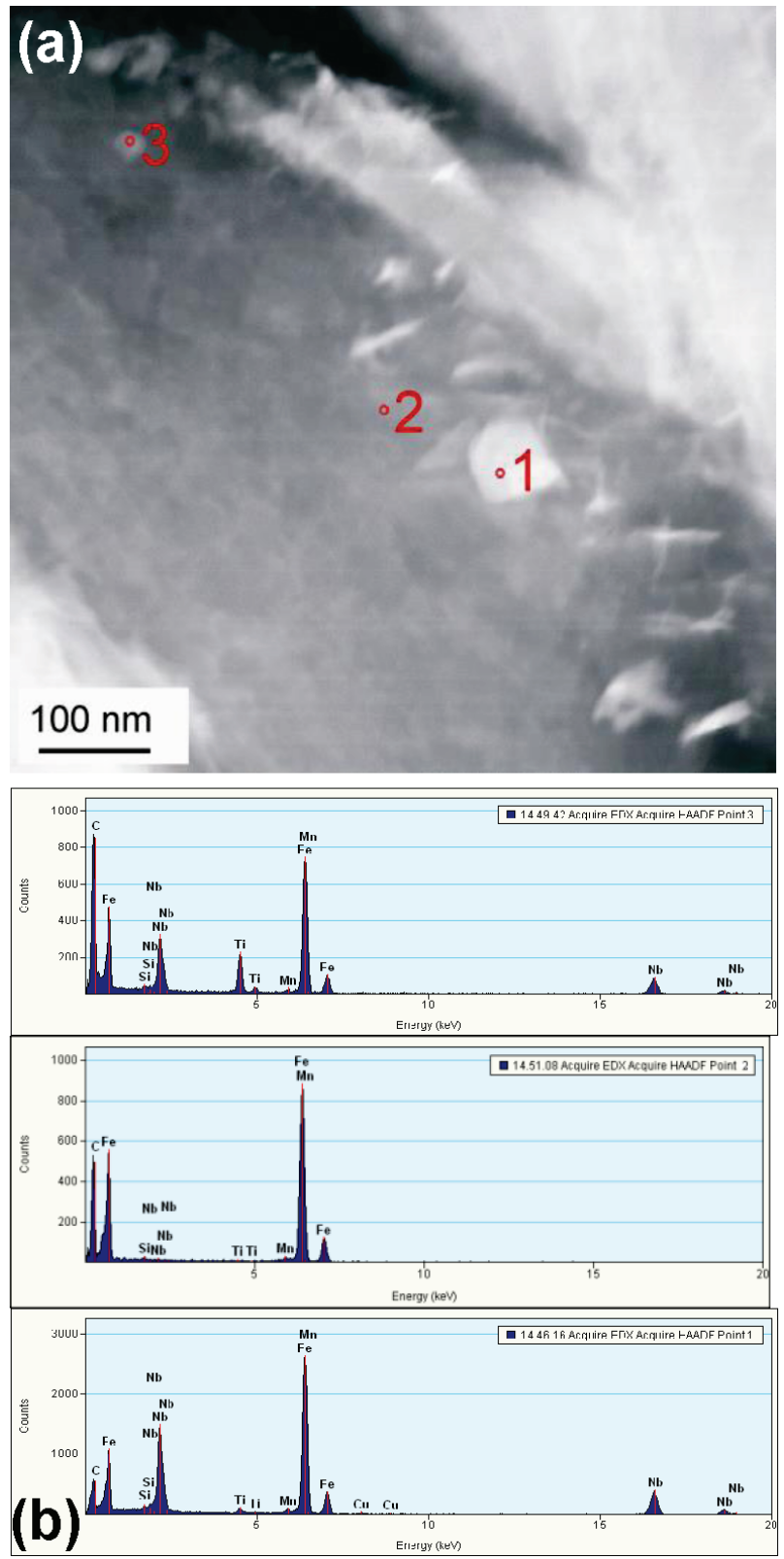

Figure 8: a) Microstructure of martensite lath with $(\mathrm{Ti}, \mathrm{Nb}) \mathrm{C}$ precipitates, b) microanalysis of micro-areas $(1,2,3)$; G1 steel, $T_{\mathrm{A}}=1200$ ${ }^{\circ} \mathrm{C}, T_{\mathrm{def}}=1100{ }^{\circ} \mathrm{C}, \dot{\varepsilon}=1.0 \mathrm{~s}^{-1}, \varepsilon=0.2, \tau_{\mathrm{w}}$ (water) $=10800 \mathrm{~s}$

Slika 8: a) Mikrostruktura martenzitne late s (Ti,Nb)C-izločki, b) mikroanaliza mikropodročij $(1,2,3)$; jeklo $\mathrm{G} 1, T_{\mathrm{A}}=1200{ }^{\circ} \mathrm{C}, T_{\mathrm{def}}=$ $1100{ }^{\circ} \mathrm{C}, \dot{\varepsilon}=1,0 \mathrm{~s}^{-1}, \varepsilon=0,2, \tau_{\mathrm{W}}($ voda $)=10800 \mathrm{~s}$

inherited in the martensite were analysed with electron diffraction and X-ray microanalysis.

The isothermal holding of the examined steel after the hot deformation results in static-precipitation processes. After a deformation at $1100{ }^{\circ} \mathrm{C}$ and an isothermal holding for $30 \mathrm{~s}$, dispersive precipitates with varied sizes and morphologies were revealed in the martensite-lath matrix with a high dislocation density (Figure 7).

In the martensite laths a TiN precipitation was revealed in the dark field (Figure $7 \mathbf{b}$ ) of the reflection from plane $(1 \overline{1} 1)_{\mathrm{TiN}}$. There are also reflections from $\mathrm{Fe}_{3} \mathrm{C}$
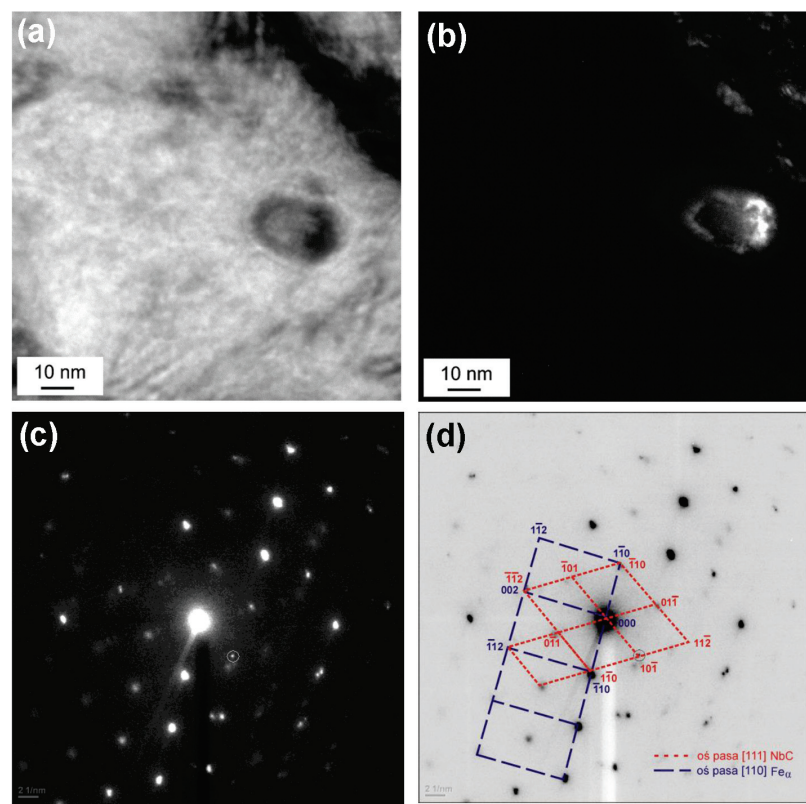

Figure 9: a) NbC spherical precipitate in martensite lath, b) image in the dark field, c) diffraction, d) diffraction solution; G1 steel, $T_{\mathrm{A}}=$ $1200{ }^{\circ} \mathrm{C}, T_{\text {def }}=900{ }^{\circ} \mathrm{C}, \dot{\varepsilon}=1.0 \mathrm{~s}^{-1}, \varepsilon=0.6, \tau_{\mathrm{w}}($ water $)=10800 \mathrm{~s}$

Slika 9: a) Okrogli izloček NbC v martenzitni lati, b) posnetek v temnem polju, c) difrakcija, d) difrakcija indeksirana; jeklo G1, $T_{\mathrm{A}}=$ $1200{ }^{\circ} \mathrm{C}, T_{\text {def }}=900{ }^{\circ} \mathrm{C}, \dot{\varepsilon}=1,0 \mathrm{~s}^{-1}, \varepsilon=0,6, \tau_{\mathrm{w}}($ voda $)=10800 \mathrm{~s}$

in the diffraction pattern, indicating the likelihood of a formation of lower bainite bands formed due to cooling. The $\mathrm{NbC}$ particles with a spherical form and a size of approximately $60 \mathrm{~nm}$ were also revealed in the martensite laths and at the former austenite-grain boundaries. In addition, at the martensite-lath boundaries, the traces of the retained austenite were revealed too. Similar results of the phase identification for microalloyed steels are also quoted in ${ }^{12-15}$.

An increase in the isothermal-holding time after the plastic deformation of the examined steel up to approximately $3 \mathrm{~h}$ results in a formation of complex titanium and niobium carbides with diverse morphologies and different chemical compositions on the bainite and martensite laths (Figure 8). A microanalysis of the polygon-shaped $(\mathrm{Ti}, \mathrm{Nb}) \mathrm{C}$ particle area of approximately 120 $\mathrm{nm}$ revealed a high concentration of $\mathrm{Nb}$ (Figure $\mathbf{8 b}$, point 1), whereas in the precipitates of $30 \mathrm{~nm}$ (Figure $\mathbf{8 b}$, point 3), comparable niobium and titanium contents were found.

The HRTEM investigations of the precipitation in the martensitic matrix of the G1 steel austenitized at $1200{ }^{\circ} \mathrm{C}$ and deformed at $900{ }^{\circ} \mathrm{C}$, with a comparable strain rate $\left(1.0 \mathrm{~s}^{-1}\right)$ and similar isothermal-holding times, but with higher pre-strains $(\varepsilon=0.6)$, allowed a determination of the morphology of the observed particles and their probable identification with the electron-diffraction method.

In the test specimens held for $44 \mathrm{~s}$ and cooled in water, there are titanium-containing nanometric precipitates of approximately $7 \mathrm{~nm}$ in the martensite-lath 
matrix. Using diffraction analysis and following the air cooling of the specimens in ferrite, precipitates of a similar size were observed and identified as TiC. After the hot deformation at $1100{ }^{\circ} \mathrm{C}$ and the same holding time (44 s) and air cooling, spheroidal precipitates ( $\mathrm{Ti}$, $\mathrm{Nb}$ ) of approximately $15 \mathrm{~nm}$ were found in the examined steel. The electron microphotographs showed that the precipitates in the martensitic matrix, especially after the deformation at $900{ }^{\circ} \mathrm{C}$, are not evenly distributed and that in many micro-areas the spacing of the particles was less than $100 \mathrm{~nm}$.

An increase in the holding time up to $185 \mathrm{~s}$ following the deformation at $900{ }^{\circ} \mathrm{C}$ results in a formation of $\mathrm{NbC}$ precipitates with a size between $20 \mathrm{~nm}$ and approximately $30 \mathrm{~nm}$ in the recrystallised austenite matrix (Figure 9). Niobium carbide precipitates were identified with electron diffraction. Their shape and distribution were revealed in the dark field of the reflection of $(10 \overline{1}) \mathrm{NbC}$ (Figures 9b to 9d). These observations indicate that the precipitation-hardening process is not uniformly distributed within the entire volume of a test specimen. It can also be assumed that the distribution of the precipitates in the solution matrix $-\alpha$ - reflexes the distribution of the preferred nucleation sites in the hot-deformed austenite substructure. However, the confirmation of this effect is difficult as the austenite substructure is subject to degradation during the phase transformation that takes place due to quench hardening. Micro-bands of twins in the martensitic matrix and precipitates in the form of discrete particles at the boundaries between these bands were identified. The chemical composition of these precipitates does not differ from that of the precipitates in the matrix.

It needs to be emphasised that $\mathrm{Nb}$ forms carbides and nitrides with equal lattices $(\mathrm{NaCl}$ type) that are completely intersoluble. The similarity of the lattices of $\mathrm{NbC}$ and $\mathrm{NbN}$ formed in the examined steel makes their precise identification difficult. As $\mathrm{NbC}$ and $\mathrm{NbN}$ form isomorphous phases in the solid solution, these precipitates can be regarded as carbonitrides. Such suggestions are made frequently. ${ }^{16}$ In addition, the results of the chemical analyses of the $\mathrm{Nb}(\mathrm{C}, \mathrm{N})$ precipitates extracted from the deformed austenite in the steels with microalloying elements confirmed that $\mathrm{Nb}$ carbonitride is rich in carbon. Compared with a stoichiometric composition, it is similar to that of $\mathrm{NbC} .^{17}$

\section{CONCLUSIONS}

The results obtained with the investigations and the analysis support the following conclusions:

1. In the examined HSLA steels microalloyed with $\mathrm{Nb}$, Ti, V and N, the precipitation of carbonitrides in both deformed and non-deformed austenite after the isothermal holding corresponds to PTT (precipitationtemperature-time) curves.
2. The precipitation of $\mathrm{NbC}, \mathrm{TiN}$ and $(\mathrm{Ti}, \mathrm{Nb}) \mathrm{C}$ during a plastic deformation of microalloyed steels (B2, G1) with torsion and compression in a temperature range of $800-1100{ }^{\circ} \mathrm{C}$ takes place in the torsion test for up to about $5 \mathrm{~s}$.

3. The static-precipitation process in microalloyed steel B2, determined by means of hot-torsion tests after an austenitization at a temperature of $1150{ }^{\circ} \mathrm{C}$ and isothermal holding at $900{ }^{\circ} \mathrm{C}$, starts after about $740 \mathrm{~s}$ and finishes after about $6200 \mathrm{~s}$. A similar process of the precipitation of steel G1, hot compressed after an austenitization at $1200{ }^{\circ} \mathrm{C}$ and isothermal holding at $1100{ }^{\circ} \mathrm{C}$ takes place in the course of holding from about $50 \mathrm{~s}$ to about $1400 \mathrm{~s}$.

4. The static precipitation of the G1 steel examined with the compression and stress-relaxation method within the temperature range of $800-1100{ }^{\circ} \mathrm{C}$ depends mainly on the pre-strain temperature and size. In the investigated deformation conditions the maximum isothermal rate of this process was found at the temperature of $900{ }^{\circ} \mathrm{C}$. The times of the beginning and the end of the static-precipitation process were about $17 \mathrm{~s}$ and about $210 \mathrm{~s}$, respectively.

5. The microstructure of the $\alpha^{\prime}$ solution matrix is formed by a partially twined martensite lath with a high dislocation density, while the precipitates with equal frequencies of the particles of single $\mathrm{NbC}$ and TiC carbides, $\mathrm{NbN}$ and TiN nitrides and also of complex $(\mathrm{Ti}, \mathrm{Nb}) \mathrm{C}$ carbides were identified with electron diffraction and energy-dispersive X-ray spectrometry (EDX).

6. The diameters of the precipitates revealed in the G1 steel range between approximately $7 \mathrm{~nm}$ and approximately $120 \mathrm{~nm}$, and their growth is proportional to the isothermal holding time after the hot deformation.

\section{REFERENCES}

${ }^{1}$ B. Dutta, C. M. Sellars, Effect of composition and process variables on $\mathrm{Nb}(\mathrm{C}, \mathrm{N})$ precipitation in niobium microalloyed austenite, Materials Science and Technology, 3 (1987) 3, 197-206, doi:10.1179/ 026708387790122846

${ }^{2}$ R. Kuziak, T. Bold, Y. W. Cheng, Microstructure control of ferrite-pearlite high strength low alloy steels utilizing microalloying additions, Journal of Materials Processing Technology, 53 (1995) 1-2, 255-262, doi:10.1016/0924-0136(95)01983-L

${ }^{3}$ E. Kalinowska-Ozgowicz, Structural and mechanical factors of the strengthening and recrystallization of hot plastic deformation of steels with microadditives, Open Access Library, 20 (2013) 2, 1-246 (in Polish)

${ }^{4}$ H. Adrian, In: Numerical Modeling of Heat Treatment Processes, AGH University of Science and Technology Publishers, Kraków 2011 (in Polish)

${ }^{5}$ M. Opiela, A. Grajcar, Elaboration of forging conditions on the basis of the precipitation analysis of MX-type phase in microalloyed steels, Archives of Civil and Mechanical Engineering, 12 (2012) 4, 427-435, doi:10.1016/j.acme.2012.06.013

${ }^{6}$ A. Grajcar, Thermodynamic analysis of precipitation processes in Nb-Ti-microalloyed Si-Al TRIP steel, J. Therm. Anal. Calorim., 118 (2014) 2, 1011-1020, doi:10.1007/s10973-014-3801-8 


\section{E. KALINOWSKA-OZGOWICZ et al.: KINETICS OF THE PRECIPITATION IN AUSTENITE HSLA STEELS}

${ }^{7}$ B. Dutta, E. J. Palmiere, C. M. Sellars, Modelling the kinetics of strain induced precipitation in Nb microalloyed steels, Acta Mater., 49 (2006) 5, 785-794, doi:10.1016/S1359-6454(00)00389-X

${ }^{8}$ W. J. Liu, J. J. Jonas, Nucleation kinetics of Ti carbonitride in microalloyed austenite, Metallurgical Transactions A, 20 (1989) 4, 689-697, doi:10.1007/BF02667586

${ }^{9}$ J. Adamczyk, E. Kalinowska-Ozgowicz, W. Ozgowicz, R. Wusatowski, Interaction of carbonitrides $\mathrm{V}(\mathrm{C}, \mathrm{N})$ undissolved in austenite on the structure and mechanical properties of microalloyed $\mathrm{V}-\mathrm{N}$ steels, Journal of Materials Processing Technology, 53 (1995) 1-2, 23-32, doi:10.1016/0924-0136(95)01958-H

${ }^{10} \mathrm{M}$. Opiela, The influence of heat treatment on microstructure and crack resistance of boron microalloyed steel plates, Journal of Achievements in Materials and Manufacturing Engineering, 43 (2010) 1, 117-124

${ }^{11}$ J. Adamczyk, Engineering of Metallic Materials, The Silesian University of Technology Publishers, Gliwice 2004 (in Polish)

${ }^{12}$ G. K. Tirumalasetty, M. A. van Huis, C. M. Fang, Q. Xu, F. D. Tichelaar, D. N. Hanlon, J. Sietsma, H. W. Zandbergen, Characterization of $\mathrm{NbC}$ and $(\mathrm{Nb}, \mathrm{Ti}) \mathrm{N}$ nanoprecipitates in TRIP assisted multiphase steels, Acta Materialia, 59 (2011) 19, 7406-7415, doi:10.1016/ j.actamat.2011.08.012
${ }^{13}$ G. K. Tirumalasetty, C. M. Fang, Q. Xu, J. Jansen, J. Sietsma, M. A van Huis, H. W. Zandbergen, Novel ultrafine $\mathrm{Fe}(\mathrm{C})$ precipitates strengthen transformation-induced-plasticity steel, Acta Materialia, 60 (2012) 20, 7160-7168, doi:10.1016/j.actamat.2012.09.025

${ }^{14}$ S. H. Mousavi Anijdan, D. Sediako, S. Yue, Optimization of flow stress in cool deformed $\mathrm{Nb}$-microalloyed steel by combining strain inducted transformation of retained austenite, cooling rate and heat treatment, Acta Materialia, 60 (2012) 3, 1221-1229, doi:10.1016/ j.actamat.2011.11.019

${ }^{15}$ H. J. Jun, K. B. Kang, C. G. Park, Effects of cooling rate and isothermal holding on the precipitation behavior during continuous casting of Nb-Ti bearing HSLA steels, Scripta Materialia, 49 (2003) 11, 1081-1086, doi:10.1016/j.scriptamat.2003.08.013

${ }^{16}$ N. Shams, Carbonitride precipitates in HSLA, Journal of Metals, 38 (1986) 5, 31-33, doi:10.1007/BF03257840

${ }^{17}$ M. J. Crooks, A. J. Garratt-Reed, J. B. Vander Sande, Precipitation and recrystallization in some Vanadium and Vanadium-Niobium Microalloyed Steels, Metallurgical and Materials Transactions A, 12 (1981) 12, 1999-2013, doi:10.1007/BF02644169 